\title{
Treating Chronic Wounds Using Photoactive Metabolites: \\ Data Mining the Chinese Pharmacopoeia for Potential Lead Species ${ }^{\#}$
}

\section{(c) (i)}

Authors

Francesca Scotti ${ }^{1}$, Linru Mou ${ }^{1}$, Chen Huang ${ }^{1}$, Anthony Booker ${ }^{1,2}$, Caroline Weckerle ${ }^{3}$, Caroline Maake ${ }^{4}$, Michael Heinrich ${ }^{1}$ (D)

Affiliations

1 Research Group "Pharmacognosy and Phytotherapy", UCL School of Pharmacy, London, UK

2 Research Centre for Optimal Health, School of Life Sciences, College of Liberal Arts and Sciences, University of Westminster. London, UK

3 Institute of Systematic and Evolutionary Botany, University of Zürich, Zürich, Switzerland

4 Institute of Anatomy, University of Zürich, Zürich, Switzerland

Key words

herbal medicines, photodynamic therapy, wound treatment, Chinese pharmacopeia, traditional medicine

received

May 15, 2021

accepted after revision

August 2, 2021

published online

September 15, 2021

Bibliography

Planta Med 2021; 87: 1206-1218

DOI 10.1055/a-1578-8778

ISSN 0032-0943

(C) 2021. The Author(s).

This is an open access article published by Thieme under the terms of the Creative Commons Attribution License, permitting unrestricted use, distribution, and reproduction so long as the original work is properly cited. (https://creativecommons.org/licenses/by/4.0/)

Georg Thieme Verlag KG, Rüdigerstraße 14,

70469 Stuttgart, Germany

Correspondence

Dr. Francesca Scotti

Research Group "Pharmacognosy and Phytotherapy”,

UCL School of Pharmacy, Univ. London

29-39 Brunswick Sq., London WC1N 1AX, UK

Phone: + 442077535844

francesca.scotti@ucl.ac.uk
Correspondence

Prof. Michael Heinrich

Research Group "Pharmacognosy and Phytotherapy”,

UCL School of Pharmacy, Univ. London

29-39 Brunswick Sq., London WC1N 1AX, UK

Phone: + 442077535844

m.heinrich@ucl.ac.uk

Supplementary material is available under

https://doi.org/10.1055/a-1578-8778

\section{ABSTRACT}

Efficient wound treatment that addresses associated infections and inflammation remains one of the big unmet needs, especially in low- and middle-income countries. One strategy for securing better healthcare can be using medicinal plants if sufficient evidence on their safety and therapeutic benefits can be ascertained. A unique novel opportunity could be photo-enhanced wound treatment with a combination of lightsensitive plant preparations and local exposure to daylight. Data mining strategies using existing resources offer an excellent basis for developing such an approach with many potential plant candidates. In the present analysis, we researched the 535 botanical drugs included in the Chinese pharmacopeia and identified 183 medicinal plant species, 82 for treating open wounds caused by trauma and 101 for inflammatory skin conditions. After further screening for reports on the presence of known photoactive compounds, we determined a core group of 10 scientifically lesser-known botanical species that may potentially be developed into more widely used topical preparations for photodynamic treatment of infected wounds. Our predictive approach may contribute to developing a more evidence-based use of herbal medicines.

\# Dedicated to Prof. Dr. Otto Sticher on the occasion of his 85th birthday. 
ABBREVIATIONS

CNKI China National Knowledge Infrastructure

CP Pharmacopoeia of the Peoples Republic of China

TCM traditional Chinese medicine

\section{Introduction}

Diverse concepts and strategies have driven the search for novel treatment options based on medicinal plants. Natural product isolation, building libraries, and their subsequent screening have been one "classical" approach [1,2], as have been ethnopharmacological ones generally focusing on small collections of often lesser-known species [3] and subsequent screening. There have been continuous efforts to develop strategies for a more stringent and evidence-based preselection, based, for example, on specific chemical parameters and rules (in the case of natural product screening or the frequency of use in ethnopharmacology). Individual species, especially those already available as herbal medicinal products, continue to be developed, often with a vision for a more evidence-based practice [4]. However, little attention has been paid to the existing generally published information on the use of medicinal plants, based on the pre-existing evidence in larger datasets and its systematic exploration. Here we explore such a strategy focusing on potential new methods for treating infected wounds based on the information available in the Pharmacopoeia of the People's Republic of China [5].

\section{Wound treatment}

The effective treatment of chronic wounds is one of the major unmet medical needs in healthcare. There is a considerable body of literature available on applying Chinese medicinal plants for the treatment of wounds. With over 2000 years of documented use, TCM has formed a unique system of medicine for the diagnosis and treatment of disease [6]. It heavily relies on plant-based medicines, with nearly 1000 medicinal plants recorded in ancient books and documents as main therapeutic agents. TCM has vast and untapped potential for evidence-based therapy [7] and modern therapeutic agents, with the $\mathrm{CP}$ [5] being a resource well worth exploring in more detail.

Wound healing is the physiological process of restoring the integrity of the skin and/or mucosae after trauma [8] Both ancient documents and modern TCM literature report medicinal plants recommended for their wound treatment properties. Medicinal plants and their active metabolites may positively stimulate or support the wound-healing process using different mechanisms. They can strengthen the interaction between various cells and growth factors on the wound surface, enhance the oxidative metabolism of the activated immune cells at the wound site, improve local microcirculation, affect the $\mathrm{pH}$ of the wound, help keep the wound moist, influence trace elements on the wound surface, and improve the expression ratio of type III and type I collagen to promote wound healing [9]. In addition, antibacterial, antiviral and antifungal effects will provide support in wound treatment. Clearly, there are potential risks associated with such uses, an as- pect that also calls for a detailed assessment of the potential and limitations of such interventions.

The CP, which is based on the theoretical concepts of TCM, distinguishes between 2 major types of wounds: wounds caused by physical trauma (like traumatic bleeding, insect and snake bites, burns, bruises, gouges, and frostbites) and inflammation-related wounds (including ulcerations, hemorrhoids, dermatitis, eczema, psoriasis, ringworm, and skin infections). Much of the previous research in this area has focused on the plants' anti-inflammatory, antimicrobial, and circulatory properties, as reported in the CP. A recently proposed strategy for identifying lead extracts and metabolites for novel topical treatments is the search for light-absorbing metabolites in species used traditionally in wound treatment, as we had detailed recently [10]. Medicinal plants combining antimicrobial and photoactivity could be reasonable candidates for photo-enhanced wound treatment, further developing photodynamic therapy (PDT) $[11,12]$. The screening of the $C P$ [5] for plants used in TCM for wound treatment and displaying both antimicrobial and photodynamic activity seems a suitable novel strategy to identify species for potential clinical application of PDT.

\section{Photoactivity}

It is well known that certain medicinal species contain photosensitizers (PSs), light-sensitive molecules that may have evolutionary evolved as part of the plant's defense system against pathogens and herbivores $[13,14]$. A very well-investigated example of a herbal PS is hypericin, a perylenequinone found in the flowers and leaves of Hypericaceae (the St. John's Wort family), which may cause pronounced skin photosensitivity (e.g., in grazing animals) [15]. Other plant-derived PSs may belong to chemical classes of furanocoumarins, polyacetylenes, xanthenoids, anthraquinones, porphyrins, thiophenes, curcuminoids, or phenalenones [16]. However, not all of these are likely to be suitable candidates due to well-known photototoxic effects and the potential absence of photosensitizing effects.

Generally, the effects of PSs after light-activation may be clinically exploited for PDT, which has shown very promising outcomes in the treatment of wounds in animals and humans, including chronic conditions such as ulcers as well as for keratosis [11, 12].

PDT has been developed in Europe from the beginning of the twentieth century and is now clinically approved worldwide as a modality against different types of cancer [17]. By attacking vital cellular components like nucleic acids, proteins, and lipids, photosensitizers may damage cells to the extent that eventually induces cell death mechanisms and locally destroy the illuminated PSbearing tissue [16].

\section{The role of PDT in wound treatment}

It has been observed that with certain "mild" PDT conditions (e.g., low photosensitizer and/or low light doses), photodynamic actions may not cause cytotoxicity but rather result in repair processes. The exact mechanisms of action responsible for PDT-promoted wound healing are not completely clear yet. However, they have been reported to relate to the proliferation and activation of wound-associated fibroblasts and the induction of acute inflam- 
mation with subsequent recruitment of immune cells and secretion of growth factors that remove damaged cells and promote the healing process, respectively $[11,12]$.

However, in cases of wounds infected with microbes, such as chronic wounds that are prone to difficult-to-treat infections, PDT may additionally exert beneficial activities since, with different natural and synthetic PSs, it had been shown to successfully kill microorganisms, including bacteria, viruses, fungi, and protozoa [18]. Especially given emerging clinical problems with multidrug-resistant bacteria, approaches such as PDT that work on drug-resistant strains and do not seem to generate resistance themselves are urgently needed. While the underlying mechanisms of antimicrobial PDT are not fully resolved for all pathogenic species, it had been proposed that it may target bacterial cell walls and/or nucleic acids and may even be effective on bacterial biofilms that are often inaccessible for common drugs [19-21]. Many in vivo wound treatment studies have focused on Staphylococcus aureus, one of the major culprits of wound infections, as well as Escherichia coli, Pseudomonas aeruginosa, and Acinetobacter baumannii $[11,12]$.

\section{Aims and Objectives}

By researching the $\mathrm{CP}[5]$ with a data mining approach, this analysis aims to identify medicinal plant species with known wound healing, anti-inflammatory and antimicrobial effects that may be combined with photodynamic protocols. In order to identify novel light-sensitive leads, the focus is on scientifically lesser-known plant species that, if known, contain compounds with absorbance maxima in the range of $250-500 \mathrm{~nm}$. Our analysis comprises the first step to develop new concepts for treating wounds, especially in low and middle-income countries.

\section{Methods}

In general terms, the data-mining approach followed 3 steps, which sequentially helped narrow down the list of species that have promising potential. Monographs are included in this paper. The approach was not strictly systematic since some of the criteria used in steps 2 or 3 are based on evidence beyond purely phytochemical and pharmacological data. This includes assessing the potential of specific single compounds known from a species as a positive criterion and excluding endangered species or those whose published relevant data were considered of poor quality and low reliability.

\section{STEP 1: Identification of plants used in TCM to treat wounds}

As the last available English edition of the CP (2015 ed.) constitutes the official modern TCM repository, it was screened for plants used to treat wounds (caused by external factors [e.g., cuts, ulcers]) and inflammatory skin conditions or infections (e.g., eczema, psoriasis). The inclusion criteria comprise ailments reported in the $\mathrm{CP}$ such as bites (often insect and snake bites), traumatic bleeding, bruises and gouges, ulcerations, burns, measles, hemorrhoids, eczema, dermatitis, ringworm, skin infections, skin rashes, psoriasis.

\section{STEP 2: Selection of plants that contain classes of metabolites known to have potential photoactivity}

The literature was searched for the included species to collect information on their metabolites, using first the $\mathrm{CP}$, then $\mathrm{CNKI}-$ 中国知网 (the official and most comprehensive scientific database in China, also covering studies that do not come from peer-reviewed sources including secondary sources [e.g., publications by Schools of TCM]), PubMed, and Science Direct.

Based on this information, the list was narrowed to species reported to contain classes of compounds considered of particular relevance for photoactivity, as listed by Siewert and Stuppner (2019), namely alkaloids, furanocoumarins, polyacetylenes, xanthenoids, anthraquinones, porphyrins, thiophenes, curcuminoids, and phenalenones [16].

\section{STEP 3: Level of evidence}

In this step, "well-studied" species were excluded based on the level of evidence available in the literature (more than 20 hits on PubMed and/or 500 hits on CNKI). At this stage, species identified as endangered were excluded and, in the case of herbal materials containing only alkaloids as compounds of interest (see step 2), based on the structural information published (when available), the lack of a chromophore was used as an exclusion criterion for the species.

Following these steps, information obtained from the literature on chemical composition, in vivo and in vitro pharmacology, clinical evidence, toxicity, and safety was critically evaluated for the selected species (see Results).

\section{Results and Discussion}

Among the 618 medicinal materials/entries/ingredients recorded in the CP, 535 are botanical drugs from 624 medicinal plant species, 376 genera, and 132 plant families [5]. Of these, 183 medicinal plant species are indicated for wound treatment. Included are species used to treat open "traumatic wounds". These may result from injuries where an external force has caused a trauma that led to a break in the skin tissue-from lacerations to bruises, burns, and abrasions. Also included are species indicated to treat inflammation-related wounds (including dermatitis, skin rash) and other related changes in physiological and biochemical conditions in the body.

In the CP, among the 183 medicinal plant species used in wound treatment, there are 112 species that, based on the presence of some metabolites (see step 2 in Methods for the list of classes considered of interest), could show potential photoactivity (see supplementary Table $1 \mathrm{~S}$ for the complete list). Among these species, those with the lowest number of literature hits (see step 3 in Methods) were further evaluated on a case-by-case basis. This led to the exclusion of endangered species (e.g., Psammosilene tunicoides W.C.Wu \& C.Y.Wu), do not contain known chromophore-bearing structures, or showed problems relating to the evidence base available, including poorly conducted studies. After applying the exclusions, there was a list of 10 species of interest (see $>$ Fig. 1 and Table 1). The selected herbal candidates were then critically evaluated concerning their potential for wound treatment, based on the chemical, pharmacological, and toxico- 


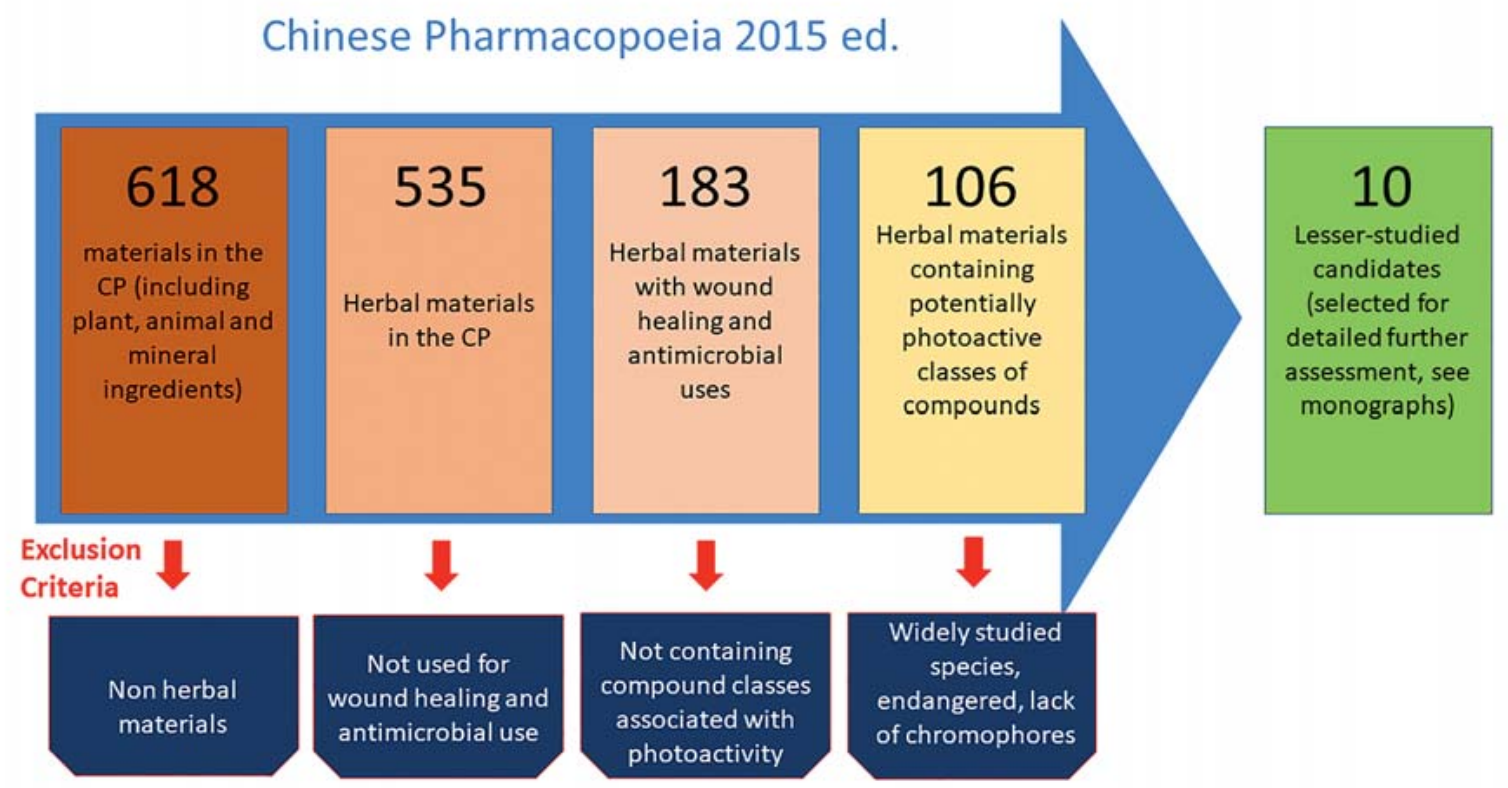

- Fig. 1 Flow chart-the overarching strategy for the data mining approach.

- Table 1 Species selected for this analysis for their applicability in the treatment of traumatic wounds and inflammatory skin conditions.

\begin{tabular}{|c|c|c|c|c|c|}
\hline Drug & Botanical source & Family & Plant part used & Use & Preparation \\
\hline Bistortae Rhizoma & Bistorta officinalis Delarbre & Polygonaceae & Dried rhizome & $\begin{array}{l}\text { Insect or } \\
\text { snake bites }\end{array}$ & Decoction, poultice \\
\hline Conyzae Herba & Eschenbachia blinii (H.Lév.) Brouillet & Asteraceae & Dried aerial part & $\begin{array}{l}\text { Traumatic } \\
\text { bleeding }\end{array}$ & Decoction, poultice \\
\hline Echinopsis Radix & $\begin{array}{l}\text { Echinops humilis M.Bieb. Echinops } \\
\text { grijisii Hance }\end{array}$ & Asteraceae & Dried root & $\begin{array}{l}\text { Dermatitis, } \\
\text { skin rashes }\end{array}$ & Decoction \\
\hline Knoxiae Radix & $\begin{array}{l}\text { Knoxia roxburghii subsp. brunonis } \\
\text { (Wall. ex G.Don) R.Bhattachariee \& } \\
\text { Deb }\end{array}$ & Rubiaceae & $\begin{array}{l}\text { Dried tuberous } \\
\text { root }\end{array}$ & Dermatitis & $\begin{array}{l}\text { External application, } \\
\text { internally in pills and } \\
\text { powder }\end{array}$ \\
\hline $\begin{array}{l}\text { Polygalae japoni- } \\
\text { cae Herba }\end{array}$ & Polygala japonica Houtt. & Polygalaceae & Aerial parts & $\begin{array}{l}\text { Insect or snake } \\
\text { bites, bruises } \\
\text { and gouges }\end{array}$ & $\begin{array}{l}\text { Decoction, powder, } \\
\text { poultice }\end{array}$ \\
\hline $\begin{array}{l}\text { Polygoni perfoliati } \\
\text { Herba }\end{array}$ & Persicaria perfoliata (L.) H.Gross & Polygonaceae & Aerial parts & $\begin{array}{l}\text { Insect or } \\
\text { snake bites }\end{array}$ & $\begin{array}{l}\text { Decoction, lotion } \\
\text { poultice }\end{array}$ \\
\hline Saururi Herba & Saururus chinensis (Lour.) Bail. & Saururaceae & $\begin{array}{l}\text { Dried aerial } \\
\text { parts }\end{array}$ & $\begin{array}{l}\text { Dermatitis, } \\
\text { eczema }\end{array}$ & Poultice \\
\hline $\begin{array}{l}\text { Semiaquilegiae } \\
\text { Radix }\end{array}$ & Semiaquilegia adoxoides (DC.) Makino & Ranunculaceae & Dried root & $\begin{array}{l}\text { Insect or } \\
\text { snake bites }\end{array}$ & Decoction \\
\hline $\begin{array}{l}\text { Siphonostegiae } \\
\text { Herba }\end{array}$ & Siphonostegia chinensis Benth & Orobanchaceae & $\begin{array}{l}\text { Dried aerial } \\
\text { parts }\end{array}$ & $\begin{array}{l}\text { Traumatic } \\
\text { bleeding }\end{array}$ & Decoction, powder \\
\hline $\begin{array}{l}\text { Trachelospermi } \\
\text { Caulis et Folium }\end{array}$ & $\begin{array}{l}\text { Trachelospermum jasminoides (Lindl.) } \\
\text { Lem. }\end{array}$ & Apocynaceae & $\begin{array}{l}\text { Dried stem with } \\
\text { leaves }\end{array}$ & $\begin{array}{l}\text { Bruises and } \\
\text { gouges }\end{array}$ & Decoction \\
\hline
\end{tabular}


<smiles></smiles>

1<smiles>[R]c1c(O)cc2c(c1Br)C(=O)c1ccccc1C2=O</smiles>

$\mathrm{R}_{1}=\mathrm{OH} \quad \mathrm{R}_{2}=\mathrm{OH}$ $5 \quad \mathrm{R}_{1}=\mathrm{OCH}_{3} \quad \mathrm{R}_{2}=\mathrm{CH}_{2} \mathrm{OH}$<smiles>c1csc(-c2ccc(-c3cccs3)s2)c1</smiles>

2<smiles>COc1cc([C@H]2CC[C@@H]3[C@H](c4ccc(O)c(OC)c4)CC[C@@H]23)ccc1O</smiles>

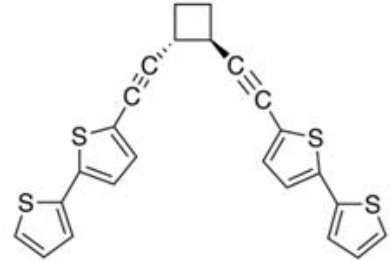<smiles>[R6]Oc1cc2c3c(cc4ccccc4c3c1)N([R8])C2=O</smiles>

$8 \quad \mathrm{R}_{1}=\mathrm{H} \quad \mathrm{R}_{2}=\mathrm{H}$

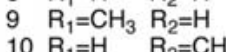

3<smiles>COc1cc(O)c2c(c1)C(=O)c1cc(C)cc(O)c1C2=O</smiles>

7

- Fig. 2 Sample metabolites, with potential relevance.

logical evidence available in published literature, and short monographs were produced for each of them.

\section{Bistortae Rhizoma}

Bistortae rhizoma consists of the roots of Persicaria bistorta (L.) Samp. (syn: Polygonum bistorta L., Polygonaceae). In the CP, B. rhizoma is designated for clearing heat and detoxifying, reducing swelling, and stopping bleeding. It is indicated for diarrhea, fever, cough, scrofula, mouth and tongue sores, hemorrhoids, and snake and insect bites. B. rhizoma shows a prominent cardiovascular protective [22], antimicrobial [23-25], anti-inflammatory [26], antitumor [27], and analgesic effects [28].

According to Wang et al., a total of 158 metabolites have been identified from B. rhizoma, including 78 from its essential oil [29]. Other metabolites include organic acids, flavonoids, phenolic acids, and alkaloids. In the CP, gallic acid is used as a quality marker in TLC. The most typical metabolites are 5-glutine-3-one and catechin with anti-oxidation and anti-inflammatory activities, respectively [29].

Liu et al. (2006) tested the antibacterial effects of ethanol extracts of $B$. rhizoma and bistortaside A (absorbance maxima at 214, 253, and $279 \mathrm{~nm}$ ); gallic acid (absorbance maximum at $269 \mathrm{~nm}$ in an acidic environment); and 1 ( $\triangleright$ Fig. 2), mururin A, a flavonolignan with absorbance maxima between 220 and $393 \mathrm{~nm}[23,30]$. Both total ethanolic extract and the individual compounds showed different degrees of inhibition on S. aureus,
E. coli, Bacillus subtilis, Bacillus proteus, Enterobacter aerogenes, $P$. aeruginosa, and S. pneumoniae, with gallic acid having the strongest bacteriostatic effect [23-25].

The plant has also shown anti-inflammatory activity that has been linked to the presence of 5-glutinen-3-one and friedelanol. In the carrageenan-induced rat paw edema model, 2 fractions obtained from the $70 \%$ ethanol extract showed a significant inhibitory effect on the rat paw edema. The effect was similar to that of positive control indomethacin [26]. After structural analysis, the 2 fractions consisted respectively of 5-glutinen-3-on and friedelanol [26].

Anthraquinones, a well-known class of photoactive compounds, have been isolated from different Polygonum species, including Persicaria (formerly Polygonum) bistorta. Included among them are the widely known emodin, chrysophanol, and aloe-emodin [31,32]. The latter has a photo yield [ $\Phi \Delta]$ of 0.54 (MeCN, $355 \mathrm{~nm}$ ) with an absorbance maximum of $430 \mathrm{~nm}$ [33].

No data on toxicity and clinical data on wound treatment activity is available for $B$. rhizoma.

\section{Conyzae Herba}

Conyzae herba is the dried aerial part of Conyza blinii H.Lév (syn: Conyza dunniana H.Lév., Asteraceae). C. Herba is recorded in the $\mathrm{CP}$ to treat lung inflammation, cough, excessive phlegm, throat pain, dental ulcer, jaundice, and traumatic bleeding. C. Herba has anti-inflammatory effects on chronic bronchitis [34], anti-ulcer ef- 
fects on gastric ulcers [35], and antitumor and bacteriostatic effects [36, 37].

The main metabolites are diterpenoids and triterpenoids, including saponins, the latter accounting for $1.6 \%$ to $3 \%$ of the metabolites in C. Herba [36]. The diterpene blinin, isolated by Yang et al. in 1989, is a marker substance for C. Herba in the CP, with the content of blinin not being less than $0.3 \%$ [38]. Other metabolites include alkenynes, flavonoids, sterols, phenylpropanoyl esters, lactones, tannins, coumarins, essential oil, and organic acids [36].

The aqueous extract of $C$. Herba had a significant inhibitory effect on Gram-positive bacteria, including S. aureus and B. subtilis, with a minimum inhibitory concentration (MIC) of $12.5 \mathrm{mg} / \mathrm{mL}$ and $50 \mathrm{mg} / \mathrm{mL}$, respectively [37]. However, no relevant effects on Gram-negative bacteria were recorded [37].

Some potentially relevant pharmacological effects of the drug if used internally have also been reported. Su et al. applied pyloric ligation-induced acute gastric ulcer in rats to test the anti-ulcer effect [39]. The results suggested that the ethanol extract of C. Herba, at the dose of $50 \mathrm{mg} / \mathrm{kg}$, significantly reduced the size of the ulcer and the content of malondialdehyde (MDA) in the gastric mucosal tissue. Further studies by Ma and Liu indicated a protective effect against gastric ulceration $[39,40]$. C. Herba can be used to treat chronic bronchitis [34].

Qi et al. tested acute toxicity on mice, guinea pigs, and cats for C. Herba. For intragastric administration in mice, the value of $L_{50}$ measured was $508 \mathrm{mg} / \mathrm{kg}$, and the maximum tolerance was $315 \mathrm{mg} / \mathrm{kg}$ [41]. The LD50 was $140 \mathrm{mg} / \mathrm{kg}$ for guinea pigs, and the maximum tolerance was $82 \mathrm{mg} / \mathrm{kg}$. The drug was given to guinea pigs by intraperitoneal injection [41]. The maximum tolerance for cats was $25 \mathrm{mg} / \mathrm{kg}$ [41]. The $\mathrm{LD}_{50}$ of the total saponins from C. Herba was $1.29 \mathrm{~g} / \mathrm{kg}$ [42].

\section{Echinopsis Radix}

Echinopsis radix is the dried root of Echinops davuricus Fisch. ex Hornem. (syn: E. latifolius Tausch., Asteraceae) or Echinops grijsii Hance, and both species are accepted as sources of the botanical drug. Importantly, before 1995, the CP did not distinguish between E. radix and Rhapontici radix (from Leuzea uniflora [L.] Holub., syn.: Rhaponticum uniflorum [L.] DC.), which were collectively recorded as Rhapontici radix.

According to the $C P$, E. radix can be used to clear heat, detoxify the body, promote lactation, reduce breast swelling and pain, and treat carbuncles, skin rash and treat tuberculosis. The photoactive tiophene $\alpha$-terthienyl is used as a chemical quality marker in the CP [43]. Thiophenes have absorption maxima in the $314-350 \mathrm{~nm}$ range [16].

E. radix contains thiophenes, flavonoids, terpenes (triterpenes and sesquiterpenes), alkaloids, steroids, and fatty acids, as well as lignans, lactones, amides, and coumarins [44,45], who have been reported for a variety of activities, including antiviral, antitumor, antifungal, anti-inflammatory hepatoprotective [46], and antibacterial [44].

The antiviral activity of $\alpha$-terthienyl (2; $>$ Fig. 2 ) specifically required 320-400 nm wavelength for activation [47], which is lower than the preferred wavelengths (around $600 \mathrm{~nm}$ ) for therapeutic applications. A variety of thiophenes has been isolated from E. radix, including 5-(but-3-en-1-ynyl)-2,2'-bithiophene, $\alpha$-ter- thienyl, cardopatine (3; > Fig. 2), and 5-acetyl-2,2'-bithiophene [48], which when photoactivated have antiviral and cytotoxic effects [43]. Irradiation of $\alpha$-terthienyl and its 15 analogs with near-UV light showed antiviral and cytotoxic effects on murine mastocytoma cells and murine cytomegalovirus while in the dark, only 5 analogs were cytotoxic and 1 was antiviral [43]. A study reported that under irradiation at $320-400 \mathrm{~nm}, \alpha$-terthienyl had antiviral activity against the human immunodeficiency virus, while in the dark or visible light, this activity was nonexistent or not apparent [47]. Under UVA radiation, $\alpha$-terthienyl inhibited the growth rate of Microsporum cookei [49], which can cause dermatophytosis such as tinea capitis. In addition, recently, 3 bithiophenes with interesting dimeric structures-echinbithiophene $\operatorname{dimers} A, B$, and $C$, isolated from $E$. davuricum-showed significant activity against different phytopathogenic fungi and 1 nematode, especially echinbithiophene dimer $\mathrm{A}$, which is comparable to the positive control, carbendazim [50].

Hong et al. studied the influence of the extraction method on the antibacterial effect of a total polysaccharide fraction isolated from the ethanol extract of $E$. radix. The fraction showed the strongest antibacterial effects on $P$. aeruginosa [51]. The decoction of $E$. radix inhibited $B$. subtilis with a MIC of $0.25 \mathrm{~g} / \mathrm{mL}$ and S. aureus and $P$. aeruginosa, both with MIC of $0.5 \mathrm{~g} / \mathrm{mL}$ [44]. In addition, Li et al. compared the antibacterial effect of different fractions of the ethanolic extract. The ethyl acetate fraction and $n$-butanol fraction had a bacteriostatic effect on S. aureus, E. coli, S. enterica, B. subtilis, and $P$. aeruginosa [52].

$\mathrm{Li}$ et al. assessed the anti-inflammatory effect of an ethanol extract of E. Radix. The total ethanol extract at the dose of $2.5 \mathrm{~g} / \mathrm{kg}$ significantly affected xylene-induced ear swelling in mice, reducing the swelling by one-third [52]. The chloroform fraction had the strongest effect, with an inhibition of $64 \%$ at the dose of $0.023 \mathrm{~g} / \mathrm{kg}$, while the inhibition rate by aspirin was $40.8 \%$ [52]. The decoction of $E$. radix also has an anti-inflammatory effect, as shown by Shuo et al. using xylene-induced ear swelling in mice and formaldehyde-induced paw edema in mice [44]. Lin et al. suggested that the main anti-inflammatory fraction of the ethanolic extract of $E$. radix was the chloroform-soluble fraction, which had a significant effect on carrageenan-induced paw edema in mice [53]. The decoction $(2.50 \mathrm{~g} / \mathrm{kg}, 5.00 \mathrm{~g} / \mathrm{kg})$ inhibited xylene-induced ear swelling in mice and reduced the number of writhing times caused by acetic acid in mice $(p<0.05)$. The decoction $(2.50 \mathrm{~g} / \mathrm{kg})$ exerted an anti-inflammatory effect on mice foot swelling caused by formaldehyde $(p<0.05)$ [54]. This suggests that $E$. radix has good anti-inflammatory and analgesic effects.

E. radix is a promising candidate in the context of PDT, considering the photoactive thiophenes as potential PSs. However, there is no clinical evidence regarding its topical application on wounds nor any studies assessing adverse events.

\section{Knoxiae Radix}

Knoxiae radix is the dried root of Knoxia roxburghii subsp. brunonis (Wall. ex G.Don) R. Bhattacharjee \& Deb (Rubiaceae). In the CP, it is listed under its synonym Knoxia valerianoides Thorel ex Pitard. with uses to treat carbuncles and sores, as a purgative and anti-ulcer agent, as well as to dislodge phlegm. 
The main bioactive metabolites of $K$. radix include anthraquinones, triterpenoids, lignans, coumarins and sitosterones [55, 56]. Several anthraquinones, well-known photoactive compounds, have been isolated. Among them are rubiadin (4; - Fig. 2) and damnacanthol (5; > Fig. 2) [57], with $\left[\Phi_{\Delta}\right]=0.34$ $\left(\mathrm{CHCl}_{3}, 377 \mathrm{~nm}\right)$, absorbance maximum $=410 \mathrm{~nm}$, and $\left[\Phi_{\Delta}\right]=$ $0.31\left(\mathrm{CHCl}_{3}, 377 \mathrm{~nm}\right)$, absorbance maximum $=350 \mathrm{~nm}$, respectively [58]. In the CP, 3-hydroxymorindone and lucidin are TLCbased quality markers. Two fractions of the ethanolic extract of K. radix showed antiviral activity on Coxsackievirus B3, an enterovirus, with $\mathrm{IC}_{50}$ values of $19.24 \mu \mathrm{M}$ and $11.11 \mu \mathrm{M}$, and one of them also inhibited influenza virus $A / H a n f a n g / 359 / 95$ with an $\mathrm{IC}_{50}$ value of $11.11 \mu \mathrm{M}$ [57]. It was reported that the $50 \%$ ethanol extract of $K$. radix has significant inhibitory effects on $E$. coli $\mathrm{K} 88$ and hemoclastic E. coli at a concentration of $0.5 \mathrm{~g} / \mathrm{mL}$, while water extracts did not exert any significant effect [59].

In assessing the acute toxicity of both the water and alcohol extract of $K$. radix, no mice died at any of the administered dosages $(24.6$ to $60.0 \mathrm{~g} / \mathrm{kg}$ ) [60]. Eyes and skin irritation tests were carried out in the same study. The water and alcohol extracts were applied into rabbits' eyes respectively and rinsed after 2 min. No sign of edema and hyperemia was observed in the eye areas [60]. A wound was cut in the shape of '\#' on one side of the rabbit's spine, then $0.1 \mathrm{~mL}$ of the extract was applied to the wound for 4 hours. The wound did not worsen, and no edema occurred, which indicated that both extracts were nonirritating to rabbit eyes and skin [60]. It needs to be highlighted that such assessments are of ethical concern and, most likely, also of limited scientific value.

In the Chinese Compendium of Materia Medica (a monograph written by Li Shizhen in the Ming dynasty), it is reported that the combination of Knoxia valerianoides and Glycyrrhiza radix should be avoided, as it can be toxic. While some preliminary data point to potential toxicity [61], the CP suggests that $K$. radix has low toxicity, and no obvious acute and subacute toxicity have so far been reported [62].

\section{Polygalae japonicae Herba}

Polygalae japonicae herba is the dried aerial part of Polygala sibirica L. (syn: Polygala japonica Houtt., Polygalaceae). Based on the $C P, P$. japonica is used to treat cough, excessive phlegm, throat pain and swelling, snake and insects bite, traumatic wounds, and sebaceous glands suppurate.

Saponins are the main metabolites of $P$. japonica, including hederagenin, tenuifolin and polygalasaponin $F$ [63]. In the CP, polygalasaponin $\mathrm{F}$ is used as a quality marker, and its content should not be less than $0.6 \%$. At present, about 54 saponins have been isolated from $P$. japonica [63]. Other metabolites include flavonoids [64], polysaccharides [65], anthraquinones (including emodin, aloe-emodin emodin-8-O- $\beta$-D-glucopyranoside and trihydroxyanthraquinone), and xanthones [66]. The plant has shown anti-inflammatory [67], analgesic [68], antitumor, cell-protective, anti-depressant [63], and anti-bacterial effects [69].

Li et al. tested the bacteriostatic effect of an oral decoction with $P$. japonica as its main ingredient. The experiment utilized 20 mice infected with S. aureus. Ten Mice were given the preparation by intragastric administration, and 10 were administered water as a control. After $24 \mathrm{~h}$, all the mice in the control group died, while the 6 mice in the drug treatment group survived $(17.5 \mathrm{~g} / \mathrm{kg})$ [70]. This result suggests that the oral decoction may improve the ability of mice to resist $S$. aureus infection [70].

The anti-inflammatory effect of $P$. japonica has been widely reported. In one study, the total saponin fraction isolated from fermented Polygalae japonicae herba, which was administered intragastrically $(6 \mathrm{~g} / \mathrm{kg})$ for 5 consecutive days, significantly inhibited xylene-induced ear swelling in mice with an inhibition rate of $42.5 \%$, while that of the positive control indomethacin was $64.6 \%$ [68]. The total saponin $(6 \mathrm{~g} / \mathrm{kg}$ ) also significantly inhibited the acetic acid-induced vascular permeability in mice with an inhibition rate of $44.7 \%$ [68]. In addition, Liu et al. investigated its analgesic effect. The total saponin fraction significantly reduced acetic acid-induced writhing numbers in mice at the dose of $6 \mathrm{~g} / \mathrm{kg}$ [68]. Two sucrose esters, tenuifolioside $B$ and ( $\beta$-D-[3-O-(3,4,5-trimethoxycinnamoyl)]-fructofuranosyl- $\alpha$-D-[6-O-(4-methoxybenzoyl)]-glucopyranoside from the root of $P$. japonica, inhibited the nitrite and PGE2 production in LPS-stimulated BV2 microglia cells with $\mathrm{IC}_{50}$ ranging from 11.7 to $22.5 \mu \mathrm{M}$ [67]. This result suggests that these 2 metabolites may be of interest for further research on neuroinflammatory diseases.

Mashed fresh Polygalae japonicae herba was applied topically to the wounds of 6 patients with a snake bite, without including a control group. The wounds' redness and swelling disappeared after 4 days, and the patients recovered after 7 days [71].

Yuan et al. performed an acute toxicity test by intraperitoneal injection on mice with an $L_{50}$ of $32 \mathrm{~g} / \mathrm{kg}$ [69]. Zhu et al. determined the acute oral toxicity of total saponins in Polygalae japonicae herba at the highest dose of $13.3 \mathrm{~g} / \mathrm{kg}$ by intragastric administration in mice. The authors did not observe death in the mice after 7 days [72].

\section{Polygoni perfoliati Herba}

Polygoni perfoliati herba is the aerial part of Persicaria perfoliata (L.) H. Gross. (Polygonaceae), and it is listed under its synonym Polygonum perfoliatum L. in the CP. Polygoni perfoliati herba is used as pectoral, and it is used in TCM, as described in the Wanbing Huichun (1615 A.D.), as a compress to treat snake and insect bites, as an aqueous decoction applied topically as a wash in cases of eczema, and as a water or wine decoction taken orally to alleviate the symptoms of other skin diseases.

More than 80 metabolites with anti-inflammatory, antibacterial, anti-hemorrhage and other activities have been isolated, including flavonoids, anthraquinones (including emodin, emodin methyl ether and aloe-emodin [73]) [74, 75] (for their photoactivity, see $B$. rhizoma), terpenoids, phenolic acid, and alkaloids [76, 77]. In the CP, quercetin is used as the quality marker using TLC. Some metabolites isolated from Polygoni perfoliati herba are useful to differentiate $P$. perfoliata from other plants in the Polygonaceae family. Homoisoflavanones have only been isolated from $P$. perfoliata and other 2 Polygonum species [78]. Two different sesquilignans have been isolated from $P$. perfoliata and $P$. orientale L., respectively, one with a 2,6-di-(substituted aryl)-cis-3,7-dioxabicyclo[3.3.0] octane skeleton and one with a tetrahydrofuran-9,9'-monoepoxy lignan structure [78]. 8-Oxo-pinoresinol (6, - Fig. 2; another 2,6-diaryl-cis-3,7-dioxabicyclo[3.3.0] octane 
lignan) was isolated from $P$. perfoliata, and it has not been reported from other species of Polygonum yet [78].

As early as 1978, in China, some scholars recorded the therapeutic effect of $P$. perfoliatum on Herpes zoster [79]. The ethanolic extract of $P$. perfoliatum exhibited antiviral activity on Herpes simplex virus-1 (HSV-1), with a viral inhibition rate of $78 \%$ [76]. This rate was close to that of the positive control, acyclovir, which was $82 \%[76]$.

The $75 \%$ ethanol extract of Polygoni perfoliati herba was shown to have a strong inhibitory effect on $S$. aureus ( $\mathrm{MIC}=$ $5 \times 10^{-2} \mathrm{mg} / \mathrm{mL}$ ), P. aeruginosa (MIC $=10 \times 10^{-2} \mathrm{mg} / \mathrm{mL}$ ), B. subtilis $\left(\mathrm{MIC}=10 \times 10^{-2} \mathrm{mg} / \mathrm{mL}\right)$, and Proteus $\left(\mathrm{MIC}=5 \times 10^{-2} \mathrm{mg} / \mathrm{mL}\right)[80]$. The ethyl acetate extract and $n$-butanol extract also had a strong inhibitory effect on $B$. subtilis and $P$. aeruginosa [80]. In addition, the ethyl acetate extract also inhibits the growth of fungi, such as Candida albicans with $\mathrm{MBC}=0.49 \mathrm{~g} / \mathrm{mL}$ [77].

In a recent study, a mouse skin wound model demonstrated the therapeutic effect of the water decoction of $P$. perfoliatum on wounds [81]. The mice were given the decoction by intragastric administration before cutting a wound on the soles of their paws. Both the decoction and the positive control dexamethasone had anti-inflammatory effects, but the former accelerated wound healing while the latter slowed it down. In this study, the percentage of wound area at different times was used as the standard to measure the degree of wound healing.

Several studies have shown the anti-inflammatory properties of Polygoni perfoliati herba. In a single cohort clinical study with no control group, by Ling, Fang, and Yang (2010), the decoction of Polygoni perfoliati herba was used topically to treat hemorrhoids with a healing rate of $92.5 \%$ [82]. The ethanol extract reduced the xylene-induced auricle swelling in mice by $82 \%$ compared to $62 \%$ for aspirin as the positive control [77]. The ethanol extract of $P$. perfoliatum could reduce the contents of prostaglandin E2 and interleukin 24 in the inflammatory tissue in the mice toe swelling model induced by carrageenan with a dose of $5 \mathrm{~g} / \mathrm{kg}$ [83]. Additionally, quercetin-3-O- $\beta$-D-glucuronide isolated from $P$. perfoliatum had a stronger anti-inflammatory effect on dimethyl benzene-induced mice ear edema than aspirin [84].

In an acute toxicity test in mice, Polygoni perfoliati herba, formulated as capsules, did not show any obvious acute toxicity $(p>0.05)$, as no deaths were recorded and major physiological functions were not altered, except for a decrease of activity within $1 \mathrm{~h}$ from administration [85].

Polygoni perfoliati herba has shown antiviral, bacteriostatic, anti-inflammatory, and hepatoprotective effects [76]. It is often applied clinically in TCM to treat skin diseases of viral origin and inflammatory gynecological conditions [76]. The bacteriostatic, antiviral, and anti-inflammatory effects might support its use in wound treatment, as suggested by the recent results of Du et al. [81]. A preliminary clinical study points to a reduction of the wound area and a shortening of the wound treatment time in traumatic infected wounds [86], but more detailed pharmacodynamic and clinical research is needed.

\section{Saururi Herba}

Saururi herba is the dried aerial part of Saururus chinensis (Lour.) Baill. (syn: Saururopsis chinensis [Baill.] Turca., Saururaceae). In the CP, Saururi herba is recorded to treat edema in the body and dysuria; as a topical application, it is recommended for infected suppurative skin and eczema.

An essential oil and many metabolites have been isolated from Saururi herba, including lignans, flavonoids, polysaccharides, polyphenols, terpenes [87], anthraquinones (including emodin and physcion, 7, • Fig. 2), and aristolactam alkaloids (8, 9, and 10 where the latter, cephalenone $B$, has an absorbance maximum in methanol at $384 \mathrm{~nm}$; Fig. 2) [88]. The lignans, including saucernetin and sauchinone, were the main bioactive metabolite [89]. Sauchinone is used as a quality marker in the CP, with a minimum content of $0.1 \%$. Flavonoids are another abundant class consisting mainly of flavonols and their glycosides, including lutein, quercetin and hyperoside [90].

Saururi herba has hepatoprotective [91], central nervous inhibiting [92], anti-inflammatory [93], blood sugar-regulating [94], antitumor [95], antiviral [96], and antibacterial [97] effects. A $70 \%$ ethanol extract and a water extract of Saururi herba are bacteriostatic on S. aureus [97]. The water extract $(8 \mathrm{~g} / \mathrm{kg})$ of Saururi herba significantly inhibited the xylene-induced ear swelling and cotton ball implantation-induced granuloma in mice by $36 \%$ and $22 \%$, respectively [93]. The water extract $(8 \mathrm{~g} / \mathrm{kg}$ ) also significantly inhibited acetic acid-induced writhing numbers in mice and raised the pain threshold of hot plated-induced pain in mice [93].

A formula with Saururi herba as the main ingredient had an inhibitory effect on skin itching caused by phosphoric histamine [98]. Wang and Zhou applied the formula lotion to the trimmed back of guinea pigs, and then $0.2 \%$ phosphoric histamine was injected subcutaneously. The inhibition rate of the lotion was $26 \%$, compared to $34 \%$ for the positive control fluocinolone acetonide [98].

The water extract, essential oil, and 95\% ethanol extracts of the aerial parts and roots were tested for acute toxicity in mice, with only the ethanol extracts showing toxicity [99]. The $\mathrm{LD}_{50}$ of $95 \%$ ethanol aerial part extract and root extract were $3.15 \mathrm{~g} / \mathrm{kg}$ and $17.15 \mathrm{~g} / \mathrm{kg}$, respectively [99].

\section{Semiaquilegiae radix}

Semiaquilegiae radix is the dried root of Semiaquilegia adoxoides (DC.) Makino (Ranunculaceae), as listed in the CP.

In the clinical application of TCM, a decoction of Semiaquilegiae radix is used to treat carbuncles, scrofula, mastitis, snake bite, tumor, and nephropathy [100]. Semiaquilegiae radix can be combined with Lonicerae Japonicae flos, Violae herba, Chrysanthemi indici flos, and Taraxaci herba in a formula named Wu Wei Xiao Du Yin (toxin dispersing beverage) to treat acne [101,102]. Lithospermoside and griffonilide are used, by the $C P$, as quality markers for the herbal material. Semiaquilegiae radix contains alkaloids, lactones, cyanogenic glycosides, phenolic acids, and at least one nitro compound [103].

Photoactive alkaloids are considered the main antibacterial active ingredients. Liu and Ji isolated berberine (11) and berberrubine (12) from Semiaquilegiae radix [104]. The 2 metabolites had bacteriostatic effects on some bacteria affecting plants, such as Ralstonia solanacearum, Erwinia carotovora pv. Carotovora, and Pseudomonas syringae pv. actinidiae. The 2 alkaloids inhibit various 
bacteria and fungi; berberine has antifungal effects on C. albicans, Cryptococcus, and dermatophytes [105]. Berberrubine has a good inhibitory effect on E. aerogenes, E. coli, Shigella castellani, and methicillin-resistant S. aureus [106]. Wang et al. (2003) tested the bacteriostatic effects of water decoction of the "toxin dispersing beverage" formula and each plant in this formula. Semiaquilegiae radix showed the best effects on $P$. aeruginosa among the 5 herbal ingredients of the formula and was also active against $S$. aureus [102].

Lithospermoside and griffonilide serve as quality markers and have also shown anti-inflammatory activity. They inhibit xyleneinduced ear swelling in mice with the dosage of $50 \mathrm{mg} / \mathrm{kg}$, and griffonilide, in particular, can inhibit inflammation by up to $64 \%$ [107].

Berberine and berberrubine are known photoactive alkaloids. Berberine has previously been experimentally applied in PDT for cancer treatment [14], showing an absorbance maximum of $420 \mathrm{~nm}$ [108], and berberrubine has shown an absorbance between 300 and $516 \mathrm{~nm}$ depending on the choice of solvent and $\mathrm{pH}$ [109].

No toxicity data is available, but there is a single major adverse event report from 2002 (trance and trembling potentially ascribable to idiosyncrasy), using the previously mentioned quintaherbal formula "toxin dispersing beverage" [110].

\section{Siphonostegiae Herba}

Siphonostegiae herba consists of the dried aerial part of Siphonostegia chinensis Benth. (Orobanchaceae). According to the CP, Siphonostegiae herba is mainly used to treat hemorrhage, bruise, abnormal menstruation, edema, and other diseases related to blood circulation. It is mostly used externally on wounds (including the juice obtained by crushing fresh plants), prepared as a decoction or soaked in yellow wine and taken orally to treat trauma.

It contains essential oil, flavonoids, alkaloids, and lignans [111]. In the CP, luteolin and acteoside are quality markers with minimal contents of $0.05 \%$ and $0.06 \%$, respectively.

The pharmacological activities of Siphonostegiae herba include hepatoprotective effects, antiplatelet aggregation, cholagogue, removing blood stasis, and antimicrobial action [111].

A decoction of Siphonostegiae herba showed bacteriostatic effects on S. aureus, Bacillus anthracis, group B Streptococcus, Corynebacterium diphtheriae, Salmonella typhi, P. aeruginosa, and Shigella dysenteriae [111].

Mice were given a drug decoction $(10 \mathrm{~mL} / \mathrm{kg})$ by intragastric administration to assess whether it promotes blood circulation using the clotting time via the angular vein method [112]. It prolonged the clotting time $(250.3 \pm 94.4 \mathrm{~s})$ compared with the normal saline group ( $133.40 \pm 16.6 \mathrm{~s})$. In addition, its effect on thrombosis in rats was determined. Measurements of the length of the clot showed that the water decoction made it shorter than the normal saline group [112].

In the acute toxicity test, mice were given a single liquid injection at a dosage of $130 \mathrm{~g} / \mathrm{kg}$. The intervention resulted in mild diarrhea in a small number of mice, but none died; this compares to using $30 \mathrm{~g}$ in humans in clinical settings. Assuming $50 \mathrm{~kg}$ for an adult patient, this suggests that Siphonostegiae herba is safe in the clinical application as the maximum tolerable dose is over 200 times higher than that used in humans [113].

\section{Trachelospermi Caulis et Folium}

Trachelospermi caulis et folium are the dried leafy stems of Trachelospermum jasminoides (Lindl.) Lem. (Apocynaceae). In TCM, Trachelospermi caulis et folium is used to clear heat, remove edema, treat swelling and painful throat, and relieve muscle spasms and injuries [114]. In other TCM documents, like Jiangxi Herbal Medicine (Revolutionary Committee of Health Bureau of Jiangxi Province, 1970), Trachelospermi caulis et folium is used as a powder for external use and soaked in wine for oral use to treat skeletomuscular pain, open wounds, and bleeding. It is classed as having compatibility with myrrh and licorice, among others, for treating sores.

Metabolites isolated from Trachelospermum caulis et folium mainly include flavonoids, lignans, triterpenes, alkaloids, anthraquinones (including emodin) [115, 116], and steroids [117]. One triterpene, tracheloside, is used as a quality marker in the $\mathrm{CP}$, with a minimum amount of $0.45 \%$ [114]. Five indole alkaloids bearing chromophores with potential photoactivity were isolated from the leaves and stems, including coronaridine, voacangine, apparicine, conoflorine, and 19-epi-voacangarine [118].

Anti-fatigue, antioxidative, antitumor, anti-inflammatory, analgesic, sedative, and hypnotic effects have been reported [114, 119-121]. The hot plate method and acetic acid writhing method were used $[122,123]$ to determine the analgesic effect of Trachelospermi caulis et folium after intraperitoneal injection or intragastric administration in mice $[122,123]$. The total flavonoids extracted from Trachelospermi caulis et folium water extract raised the pain threshold of hot plate reaction in mice and reduced writhing. The total flavonoids inhibited ear swelling and toe swelling in mice [123].

Apparicine has demonstrated potential in treating gout by inhibiting xanthine oxidase in vitro with an $\mathrm{IC}_{50}$ of $0.65 \mu \mathrm{M}$, while the positive control allopurinol had an $\mathrm{IC}_{50}$ of $0.60 \mu \mathrm{M}$ [124]. It is worth noting that voacangine has shown antiangiogenetic activity both in vitro and in vivo, which could be detrimental while treating wounds [125].

The existing literature focuses on its antifatigue, sedative, antitumor, antioxidative, and hypolipidemic effects. Studies on antibacterial activity are lacking. Overall research on Trachelospermi caulis et folium is very limited and lacks clinical data.

\section{Future Research on Plants Identified as Potential Leads for PDT Therapies}

This data-mining study explored the CP to identify potential leads for developing PDT-based herbal medicinal products for wound treatment. Candidate species were selected based on their traditional use in TCM for diseases (as defined in the context of the CP) that could be linked to antimicrobial properties and the treatment of different types of wounds/skin inflammation. The candidates were then assessed ethnopharmacologically based on the existing chemical, pharmacological, and toxicological evidence, including 
species that can be used based at least in part on photoactive metabolites. The species were identified using a combination of criteria as defined above. However, this approach requires integrating information from different categories of data-phytochemistry, photoactivity, pharmacology/microbiology-and, in many cases, very limited information is available on the photoactivity of the metabolites. When available, such information is for single compounds, while the specific aim of the wider project is to identify easy-to-use extracts as potential leads. Such leads can then be developed into preparations with a clearly defined profile of quantified marker compounds. Importantly, the activity may well be a combination of effects of different (classes of) compounds with or without photoactivity.

In this data mining step, we had to take a broad perspective, looking at classes of compounds that contain well-known photoactive compounds (as defined, for example, by Siewert and Stuppner (2019) [16]. We decided to focus on lesser-known species since these may offer the greatest chemobiological potential. In the next steps, a detailed chemical characterization combined with an assessment of the extracts' and compounds' photo and pharmacological activity will be required. Those with the most promising activity profile will be further assessed in more mechanistic in vitro and in vivo models.

\section{Conclusion}

After a systematic assessment of the 618 medicinal materials (botanical ones and other drugs derived from natural sources) included in the CP, we identified 10 species that may be relevant for future studies on photodynamic treatments of infected wounds. In more general terms, the approach used here offers a novel strategy to base the primary selection of species on an empirical basis using existing large-scale datasets, such as the CP. This analysis does not consider the Chinese traditional medical concepts and is not in a strict sense based on TCM concepts.

Further steps of this research will assess target species to make easy-to-prepare extracts available as a low-cost first aid intervention in lower- and middle-income countries. In this context, the project is not about "drug discovery" in the sense of identifying "new" compounds but developing phytotherapeutic preparations with the extract being the active agent (i.e., a therapy based on the combined effects of different classes of natural products-a planta medica). In the later stages of the project, defined production processes and methods for quality control will be required. However, if found, new single photoactive compounds would not be excluded and may well be another outcome of the later stages of this project.

Data mining is proposed here as a strategy for systematically and rationally selecting species to be assessed pharmacologically. Existing datasets with albeit preliminary evidence are used as a basis for selecting species to be investigated experimentally on different targets and diseases. This approach offers a broader basis in terms of chemo-biodiversity, and thus, we expect that it would be much more likely to successfully enable the development of herbal medicinal interventions, which are efficient and safe to use, provided that the material can be sourced sustainably based on access and benefit agreements, as required.

\section{Supporting Information}

A list of the botanical drugs from the CP that, based on some metabolites, could show potential photoactivity (Table 1S) is provided as supporting information.

\section{Contributors' Statement}

$\mathrm{M}$. H. designed the study and supervised the project including an MSc dissertation by $\mathrm{CH}$ and an MRes dissertation by LM, who gathered the data and provided an analysis. F. S. contributed to the design and the supervision of LM and led in the analysis of the chemical data. A. B. contributed aspects esp. relating to plant sciences and ethnopharmacology, C.W. on the taxonomy and botany, C.M. on photodynamic aspects. All authors read the MS and approved the final version.

\section{Acknowledgements}

Funding by Velux Stiftung (Switzerland), aiming at developing plant extracts into a PDA-based therapeutic option for use in low- and middleincome countries, is gratefully acknowledged. Chloe Huang conducted this research as a part of her MSc project at the Faculty of Life Sciences of UCL and Linru Mou as part of an MRes project at the School of Pharmacy (UCL).

Conflict of Interest

The authors declare that they have no conflict of interest.

\section{References}

[1] Sticher O. Natural product isolation. Nat Prod Rep 2008; 25: 517-554

[2] Wilson BAP, Thornburg CC, Henrich C], Grkovic T, O'Keefe BR. Creating and screening natural product libraries. Nat Prod Rep 2020; 37: 893-918

[3] Heinrich M. Ethnopharmacology and Drug Development. In: Mander L, Lui HW, eds. Comprehensive natural Products II Chemistry and Biology. Elsevier: Oxford; 2010: 351-381

[4] Sticher O. Biochemical, pharmaceutical, and medical Perspective of Ginseng. In: Larry D L, Rudolf B, eds. Phytomedicines of Europe. ACS symposium series 1998; 691: 221-240

[5] National Pharmacopoeia Commission of China. Pharmacopoeia of People's Republic of China, 2015 edition. China: China Medical Science Press; 2015: 1

[6] Leon C, Lin Y. Chinese medicinal Plants herbal Drugs and Substitutes: An Identification Guide. Richmond, UK: Kew Press; 2017

[7] Wang J, Wong YK, Liao F. What has traditional Chinese medicine delivered for modern medicine? Expert Rev Mol Med 2018; 20: e4

[8] Wang PH, Huang BS, Horng HC, Yeh CC, Chen YJ. Wound healing. J Chin Med Assoc 2018; 81: 94-101

[9] Feng X, Zhou Y, Fang D. Study on the mechanism of traditional Chinese medicine intervention effect on wound healing. J Liaoning Tradit Chin Med 2015; 42: 1498-1501

[10] Heinrich M, Jiang H, Scotti F, Booker A, Walt H, Weckerle C, Maake C. Medicinal plants from the Himalayan region for potential novel antimicrobial and anti-inflammatory skin treatments. J PharmPharmacol 2021; 73: 956-967

[11] Oyama J, Fernandes Herculano Ramos-Milaré ÁC, Lopes Lera-Nonose DSS, Nesi-Reis V, Galhardo Demarchi I, Alessi Aristides SM, Juarez Vieira Teixeira J, Gomes Verzignassi Silveira T, Campana Lonardoni MV. Photodynamic therapy in wound healing in vivo: a systematic review. Photodiagnosis Photodyn Ther 2020; 30: 101682 
[12] Sun Y, Ogawa R, Xiao BH, Feng YX, Wu Y, Chen LH, Gao XH, Chen HD. Antimicrobial photodynamic therapy in skin wound healing: a systematic review of animal studies. Int Wound J 2020; 17: 285-299

[13] Mansoori B, Mohammadi A, Amin Doustvandi M, Mohammadnejad F, Kamari F, Gjerstorff MF, Baradaran B, Hamblin MR. Photodynamic therapy for cancer: Role of natural products. Photodiagnosis Photodyn Ther 2019; 26: 395-404

[14] Muniyandi K, George B, Parimelazhagan T, Abrahamse H. Role of photoactive phytocompounds in photodynamic therapy of cancer. Molecules 2020; 25: 4102

[15] Stegelmeier BL, Davis TZ, Clayton MJ. Plant-induced photosensitivity and dermatitis in livestock. Vet Clin North Am Food Anim Pract 2020; 36: 725-733

[16] Siewert B, Stuppner H. The photoactivity of natural products-an overlooked potential of phytomedicines? Phytomedicine 2019; 60: 152985

[17] Rkein AM, Ozog DM. Photodynamic therapy. Dermatol Clin 2014; 32 : $415-425$

[18] Ghorbani J, Rahban D, Aghamiri S, Teymouri A, Bahador A. Photosensitizers in antibacterial photodynamic therapy: An overview. Laser Ther 2018; 27: 293-302

[19] Cieplik F, Deng D, Crielaard W, Buchalla W, Hellwig E, Al-Ahmad A, Maisch T. Antimicrobial photodynamic therapy-what we know and what we don't. Crit Rev Microbiol 2018; 44: 571-589

[20] Grinholc M, Nakonieczna J, Fila G, Taraszkiewicz A, Kawiak A, Szewczyk G, Sarna T, Lilge L, Bielawski KP. Antimicrobial photodynamic therapy with fulleropyrrolidine: Photoinactivation mechanism of Staphylococcus aureus, in vitro and in vivo studies. Appl Microbiol Biotechnol 2015; 99: 4031-4043

[21] Schafer M, Schmitz C, Facius R, Horneck G, Milow B, Funken K, Ortner ]. Systematic study of parameters influencing the actio of rose bengal with visible light on bacterial cells: Comparison between the biology effect and singlet-oxygen production. Photochem Photobiol 2000; 71: 514523

[22] Huang Z, Li L, Chen X, Xiao H, Zeng J. The therapeutic effects of Polygonum bistorta L. n-butyl alcohol on isolated heart ischemia of reperfusion injury. Sichuan Tradit Chin Med 2009; 27: 52-54

[23] Liu X, Li W, Li X, Xia H, Chen F. Preliminary study on in vitro antimicrobial activity of extracts and monomer compounds of Polygonum bistorta L. Chin Tradit Herb Drugs 2006; (1): 51-53

[24] Liu C, Wang X, Zeng J. Preliminary study on antimicrobial activity of Polygonum bistorta L. J Gannan Med Coll 2006; (4): 489-490

[25] Wang G, Fei H, Zhao X, Zhao Y. The in vitro antibacterial activity of the total flavonoids from Polygonum bistorta L. J Taishan Med Coll 2019; 40: $410-412$

[26] Duwiejua M, Zeitlin IJ, Gray Al, Waterman PG. The anti-inflammatory compounds of Polygonum bistorta: isolation and characterisation. Planta Med 1999; 65: 371-374

[27] Liu YH, Weng YP, Lin HY, Tang SW, Chen C], Liang C], Ku CY, Lin JY. Aqueous extract of Polygonum bistorta modulates proteostasis by ROSinduced ER stress in human hepatoma cells. Sci Rep 2017; 7: 1-15

[28] Huang Y, Zeng J, Ye H, Huang S, Lai F. A study on the analgesic effect of Polygonum bistorta L. n-Butyl alcohol. J Gannan Med Coll 2004; 24: 12 13

[29] Wang H, Huang B, Zhan Z, Huang L, Liu D, Du H. Latest research progress of chemical constituents and pharmacological activities of Polygonum bistorta L. Mod Tradit Chin Med Mater Medica-World Sci Technol 2020; 22: 2998-3007

[30] Takashima J, Asano S, Ohsaki A. Mururins AC, three new lignoids from Brosimum acutifolium and their protein kinase inhibitory activity. Planta Med 2002; 68: 621-625

[31] Xianling Y. Optimization of the extraction process of anthraquinones by response surface methodology. Chin Arch Tradit Chin Med 2013; 31 : $408-410$
[32] Shen BB, Yang YP, Yasamin S, Liang N, Su W, Chen SH, Wang XJ, Wang W. Analysis of the phytochemistry and bioactivity of the genus Polygonum of Polygonaceae. Digit Chin Med 2018; 1: 19-36

[33] Vath P, Wamer WG, Falvey DE. Photochemistry and phototoxicity of Aloe emodin. Photochem Photobiol 2002; 75: 346-352

[34] Qi Y. Therapeutic effect of Conyza herba resin aerosol on 188 cases of chronic tracheitis of wheezing type and pharmacological experiment study. J Mod Clin Med 1979; (1): 42-48

[35] Ma J, Li J, Su Y, Zheng J. Effect of Conyza herba on pyloric ligation of gastric ulcer in rats and its mechanism. Chin Pharmacol Bull 2000; 17: 55

[36] Sun R, Gao JL, Liu S. Research progress on Conyza blinii. Chin Tradit Herb Drugs 2018; 49: 4710-4714

[37] Wang Y, Nie L, Fang L, Tang N, Lei Y, Jin W, Tang Z, Chen H. In vitro analysis on antibacterial activity of extract from Conyza blinii $\mathrm{H}$. Lév. Genomics Appl Biol 2019; 38: 2200-2226

[38] Yang CR, He ZT, Li XC, Zheng QT, He CH, Yang J, Morita T. Blinin, a neoclerodane diterpene from Conyza blinii. Phytochemistry 1989; 28: 3131 3134

[39] Su Y, Chen L, Luo Y, Chai X, Lv M, Guo D. Chemical constituents and their antiulcerogenic studies on whole herb of Conyza blinii. Chin Tradit Herb Drugs 2007; 38: 332-334

[40] Ma L, Liu J. The protective activity of Conyza blinii saponin against acute gastric ulcer induced by ethanol. J Ethnopharmacol 2014; 158: 358-363

[41] Qi Y, Xu X, He H, Wang S, Yang C. Preliminary experimental research on the total saponin of Conyza herba. Chin Tradit Pat Med 1983;: 36

[42] Sichuan Chengdu Conyza Herba Treating Chronic Tracheitis Cooperative group. The drug and clinical study of Conyza herba in the treatment of chronic tracheitis. J New Med 1976; 7: 260-262

[43] Marles RJ, Hudson JB, Graham EA, Soucy-Breau C, Morand P, Compadre RL, Compadre CM, Towers GHN, Arnason JT. Structure-activity studies of photoactivated antiviral and cytotoxic tricyclic thiophenes. Photochem Photobiol 1992; 56: 479-487

[44] An S, Ge H, Liu Y, Li S, Zhang L. Anti-inflammatory analgesic and antibacterial effects of Echinopsis radix. J Henan Med Coll 2019; 31: 252-255

[45] Sandjo LP, Kuete V, Siwe XN, Poumale HMP, Efferth T. Cytotoxicity of an unprecedented brominated oleanolide and a new furoceramide from the Cameroonian spice, Echinops giganteus. Nat Prod Res 2016; 30: 2529-2537

[46] Wang Y, Li X, Zhang P. Research progress on chemical constituents and pharmacological activities of Echinopsis Radix. Chin Tradit Herb Drugs 2005; 36: 309-311

[47] Hudson JB, Harris L, Teeple A, Towers GHN. The anti-HIV activity of the phytochemical $\alpha$-terthienyl. Antiviral Res 1993; 21: 33-43

[48] Wang Y, Li X, Meng D, Li N, Zhang Y. Chemical constituents of thiophenes from Echinops latifolius Tausch. J Shenyang Pharm Univ 2008; 25: 194-196

[49] Mares D, Fasulo MP, Bruni A. Ultraviolet-mediated antimycotic activity of $\alpha$-terthienyl on Microsporum cookei. J Med Veterinary Mycol 1990; 28 : 469-477

[50] Wu HB, Wu HB, Kuang MS, Lan HP, Wen YX, Liu TT. Novel bithiophene dimers from echinops latifolius as potential antifungal and nematicidal agents. J Agric Food Chem 2020; 68: 11939-11945

[51] Hong J, Hu J, Zhang H, Liu K, Liu B. The influence on the content and antimicrobial antioxidant activity of polysaccharide extraction from radix Echinopsis by different extraction methods. Food Sci Technol 2017; 42: 232-235

[52] Li X, Zhang W, Wang Y, An S, Zhu Y. Screening effective part of Echinopsis radix via bacteriostasis and anti-inflammatory activities. Chin J Exp Tradit Med Formulae 2015; 21: 138-141

[53] Lin CC, Lin CH, Chiu HF, Hu MF. The pharmacological and pathological studies on Taiwan folk medicine (VII): The anti-inflammatory effect of Echinops griiisii. Am J Chin Med 1992; 20: 127 
[54] Dai W, Liu Y, Liu Y, Zhai W, Qiao Y. Phototoxicity assessment of radix Echinopsis based on chemiluminescence method. Chin J Exp Tradit Med Formulae 2012; 18: 185-187

[55] Zhao F, Wang S, Wu X, Yu Y, Yue Z, Liu B, Lin S, Zhu C, Yang Y, Shi J. Non-anthraquinones constituents from the roots of Knoxia valerianoides. China J Chin Mater Medica 2012; 37: 2092-2099

[56] Hong Y, Ma L, Wang Y, Sun J, Hou G, Zhao F, Han J, Wang C. Anthraquinones and triterpenoids from roots of Knoxia roxburghii. China J Chin Mater Medica 2014; 39: 4230-4233

[57] Hänsel R. Sticher O. Pharmakognosie - Phytopharmazie, 7th edition. Berlin: Springer-Berlin; 2010: 381

[58] Comini LR, Núñez Montoya SC, Sarmiento M, Cabrera JL, Argüello GA. Characterizing some photophysical, photochemical and photobiological properties of photosensitizing anthraquinones. J Photochem Photobiol A Chem 2007; 188: 185-191

[59] Xu H, Song Y. Bacteriostatic experiment of twelve species of Chin medicines and its compounds against Escherichia coli. Sichuan Anim Vet Sci 2004; 31: 24-25, 28

[60] Li X, Zhong L, Wang J. Study on acute toxicity and irritation of Euphorbia pekinensis and Knoxia valerianoides. China Pharm 2013; 24: 208-209

[61] Yang Z, Wang Y, Wu C, Huang Y, Wang Q, Cheng X, Chen H. Toxicity experiment on Sargassum, radix Knoxiae, radix Ransul and flos Genkwa against radix Glycyrrhizae in the antagonism of 18 Chinese drugs. China J Chin Mater Medica 1989; 14: 48-50

[62] Yang X. Study on toxicity of Knoxiae Radix and active components and quality standards of Gendarussa vulgaris [Dissertation]. Shanghai: Shanghai University of Traditional Chinese Medicine; 2013

[63] Zhang J, Wang X, Cui Z, Hu Z, Ding S, Huang X. Advances on chemical constituents and pharmacological activities of Polygala japonica Houtt. Mod Chin Med 2015; 17: 1216-1222

[64] Li TZ, Zhang WD, Yang G], Liu WY, Liu RH, Zhang C, Chen HS. New flavonol glycosides and new xanthone from Polygala japonica. J Asian Nat Prod Res 2006; 8: 401-409

[65] Zhang D, Dan W. Chemical constituents from roots of Polygala japonica. Chin Tradit Herb Drugs 2005; 36: 1767-1771

[66] Xue QC, Li C], Zuo L, Yang JZ, Zhang DM, Xue C. Three new xanthones from the roots of Polygala japonica Houtt. J Asian Nat Prod Res 2009; 11: 465-469

[67] Quang TH, Cong PT, Yen DTH, Nhiem NX, Tai BH, Yen PH, Ngan NTT, Kim DC, Kim YC, Oh H, Minh CV, Kiem PV. Triterpenoid saponins and phenylpropanoid glycosides from the roots of Polygala japonica Houtt. with anti-inflammatory activity. Phytochem Lett 2018; 24: 60-66

[68] Liu M, Zhu T, Guo S, Zhu H. Evaluation of the anti-inflammatory and analgesic activities of the total saponins extracted from fermented Polygala japonica HOUTT. Adv Mater Res 2013; 641-642: 931-934

[69] Yuan M, Wan F. Observation of the antibacterial and analgesic effect of formula Polygala japonica Houtt. Chin Pharm J 1985; 20: 313

[70] Li ], Nie Z, Zhu J. Experimental study on pharmacological action of formula Polygala japonica Houtt. oral liquid. Chin Tradit Pat Med 1997; 19: 35-36

[71] Xu H. Polygala japonica Houtt. for topical treatment of snake bites. Chin Folk Ther 2011; 19: 20

[72] Zhu T, Liu M, Guo S, Li X, Wang X. Study on the anti-inflammatory and analgesic effect of total saponin from fermented Polygala japonica Houtt. Chin J Hosp Pharm 2011; 31: 996-998

[73] Morton RA, Earlam WT. Absorption spectra in relation to quinones: 1: 4-naphthaquinone, anthraquinone, and their derivatives. J Chem Soc 1941: 159-169

[74] Huang G, Guo X, Li W, Xu L. Research progress on chemical compositions and pharmacological activities of Polygonum perfoliatum L. Guangzhou Chem Ind 2017; 45: 26-28
[75] Matsuda H, Shimoda H, Morikawa T, Yoshikawa M. Phytoestrogens from the roots of Polygonum cuspidatum (Polygonaceae): Structure-requirement of hydroxyanthraquinones for estrogenic activity. Bioorganic Med Chem Lett 2001; 11: 1839-1842

[76] Liu J, Zeng Y, Sun G, Yu S, Xu Y, He C, Li Z, Jin S, Qin X. Polygonum perfoliatum L., an excellent herbal medicine widely used in China: A review. Fr Pharmacol 2020; 11: 581266

[77] Huang H, Zhang C, Yuan D, Zhou Z. Anti-inflammatory and antibacterial effects of Polygonum perfoliatum L.: an active site research. Anhui Med Pharm J 2008; 12: 595-596

[78] Lei J, Yao N, Wang KW. Phytochemical and chemotaxomic study on Polygonum perfoliatum L. Biochem Syst Ecol 2013; 48: 186-188

[79] Yang $\mathrm{H}$. The therapeutic effect of Polygonum perfoliatum L. on herpes zoster. J New Chin Med 1978; 3: 18

[80] Huang X, Jiang L, Wang S, Jiang X, Huang D. Antibacterial activity research of medical plants of Persicaria perfoliata. J Mod Med Heal 2013; 29: $3041-3044$

[81] Du J, Xiao H, Du G. Wound healing action and mechanism of Polygonum perfoliatum L. J Henan Univ Sci 2020; 39: 381-384

[82] Liu Y, Fan W. Research progress of pharmacological effects and clinical application of Gangbangui. Asia-Pacific Tradit Med 2011; 7: 161-162

[83] Long W, Li Y. Experimental study on the effect of relieving cough and reducing sputum of Polygonum perfoliatum L. Chin J Clin Ration Drug Use 2010; 3: 34-35

[84] Fan D, Zhou X, Zhao C, Chen H, Zhao Y, Gong X. Anti-inflammatory, antiviral and quantitative study of quercetin-3-O- $\beta$-D-glucuronide in Polygonum perfoliatum L. Fitoterapia 2011; 82: 805-810

[85] Liu J. Result analysis of compound Gangbangui capsule used in acute toxicity experiment in mice. Electron J Clin Med Lit 2017; 4: 4967, 4970

[86] Yang $\mathrm{H}$, Zhou L, Wu H, Hu J. A clinical study on the curative effect and mechanism of action of external applications of antipyretic detoxicate traditional Chinese drugs for treatment of traumatic infected wounds. J Tradit Chin Orthop Traumatol 2016; 28: 13-18, 23

[87] Sui ], Li F, Guo Y, Wei B, Jiang L. Research progress on chemical composition and pharmacological effects of Saururus chinensis and predictive analysis on quality marker. Sci Technol Food Ind 2020; 41: 353-360

[88] Wang EC, Shih MH, Liu MC, Chen MT, Lee GH. Studies on constituents of Saururus chinensis. Heterocycles 1996; 43: 969-975

[89] Chen H, Li X, Chen J. A study on the chemical constituents of the above ground parts of Saururus chinensis(2). Chin Pharm J 2019; 54: 360-363

[90] Sun D, Duan F, Jiang J, Liao X, Xiang Z, Li S. Simultaneous determination of five flavonoid contents from the different drying process of Saururus chinensis (Lour.) Baill. by UPLC. J Guangdong Pharm Univ 2019; 35: 506 510

[91] Xu C, Li X, Chen H, Wu Y. Research on the effect of contents from Saururus chinensis on $\mathrm{H}_{2} \mathrm{O}_{2}$-induced $\mathrm{LO} 2$ cell damage. J Nanjing Univ Tradit Chin Med 2012; 28: 163-164

[92] Huang K, Pan L, Xiao D, Luo Y. Experimental study on central inhibition of chloroform extract from Saururus chinensis. Lishizhen Med Mater Medica Res 2015; 26: 1054-1055

[93] Zeng W, Yu Y, Wang Y, Zhou L, Chen J. Research on the anti-inflammatory and analgesic effect of Saururus chinensis. China Med Her 2012; 9: 33-35

[94] Xing D, Su S. Effects of total flavonoids of Saururus chinensis (Lour.) Baill on glucose and lipid metabolism in type II diabetic insulin resistance rats. Chin Tradit Pat Med 2013; 37: 1840-1842

[95] Lv H, Zou L, Ma J, Wang S, Liu T, Ke X, Fu J. Anti-metastatic effects of extracts from Saururi Herba downregulating Runx2 activation on breast cancer. Chin J Exp Tradit Med Formula 2015; 21: 123-127

[96] Tian L, Li X, Xu Y, Li E. Effect and mechanism of Saururus chinensis against herpes simplex virus. China J Chin Mater Medica 2012; 37: 1642-1645 
[97] Zhou J, Zhou L, Hou X, Liu Z. Study on in vitro antimicrobial activity of two extracts of Saururus chinensis. Jiangsu Agricutural Sci 2012; 40: 234-235

[98] Wang Y, Zhou L. Pharmacological study on external lotion of Saururi Herba. J Pract Tradit Chin Intern Med 2000; 14: 11-12

[99] Chen H, Li X, Chen J. Studies on the acute toxicity of Saururus chinensis extract from different medicament portions. China Med Her 2013; 10: 13-15

[100] Feng S, He X, Kai O, Chen F, Huang Y. Optimization on total alkaloids extraction from Semiaquilegia adoxoides using response surface methodology and evaluation of its antioxidant activity in vitro. Tradit Chin Drug Res Clin Pharmacol 2018; 29: 199-204

[101] Lin C, Zhang Y, Lu Y. Effect analysis of toxin dispersing beverage on purulent acne. J North Pharm 2019; 16: 84

[102] Wang Z, Xiao R, Zhang L, Song Y. Bacterial inhibition test of toxin dispersing beverage on suppurative bacteria. Sichuan Anim Vet Sci 2003; 30: $20-21$

[103] Zhang H, Chen H, Shen W, Yan Q, Tan J, Xu C, Fan H, Miao J, Sun S. Research Progress on chemical constituents from Radix Semiaquilegiae. J Nanjing Med Univ 2018; 34: 205-209

[104] Liu X, Ji Z. Studies on chemical constituents and antibacterial activity of Semiaquilegia adoxoides. Nat Prod Res Dev 2019; 31: 1177-1182

[105] Han Y, Liu H, Li K, Dan T, Ge X. Research progress on antifungal activity of berberine and synthesis of its molecular probes. Chem World 2020; 61: 83-91

[106] Wang G, Qi F, Gao Y, Xi Y, Zhang Z. Progress in preparation and application of berberrubine and derivatives. Yunnan Chem Technol 2020; 47: 1-8

[107] Niu F. Studies on the constituents and quality control of Semiaquilegia adoxoides [Dissertation]. Shenyang: Shenyang Pharmaceutical University; 2006

[108] Görner H, Miskolczy Z, Megyesi M, Biczók L. Photoreduction and ketone-sensitized reduction of alkaloids. Photochem Photobiol 2011; 87: 284-291

[109] Gasparec Z, Lovric SK, Lovric M. The ultraviolet and visible absorption spectra of berberrubine. Can J Chem 1982; 60: 970-975

[110] Zhang B. A case report of Tiankuizi poisoning. Shanxi J Tradit Chin Med 2002; 23: 843

[111] Wang F, Liu J. Research progress on chemical constituents and pharmacological effects of Siphonostegia chinensis Benth. Heilongjiang Med Pharm 2008; 31: 61
[112] Sun W, Pan Y, Guo X, Jin R, Fu S, Wu Z, Chen D, Jin L. Comparison study in blood-flow-promoting and blood-stasis-removing effects of Artemisia anomala S.Moore and Siphonostegia chinensis Renth. Acad J Shanghai Univ Tradit Chin Med 1997; 11: 68-72

[113] Liu Y, Chen S. The comparison of pharmacological activity between Siphonostegia chinensis Benth. and Artemisia capillaris Thunb. Chin Tradit Herb Drugs 1994; 17: 38-40

[114] Wang H, Chen X, Qiu H, Liu S. Research status of Trachelospermum jasminoides (Lindl.) Lem. Guid Chin Med 2012; 10: 93-94

[115] Zhang J, Yin Z, Liang J, Diao Y. Chemical constituents from petroleum ether extract of Trachelospermum jasminoides. Chin Tradit Pat Med 2012; 34: 1939-1942

[116] Tao J, Bo K, Wei Y, Wu C, Min J, Xing X, Xi X. Network pharmacology to identify the pharmacological mechanisms of a traditional Chinese Medicine derived from Trachelospermum jasminoides in patients with rheumatoid arthritis. Med Sci Monit 2020; 26 (e922639): e922639(1)-e922639(14)

[117] Tang X, Chen H, Zhou M, Zhang Y. Triterpenoids from canes with leaves of Trachelospermum jasminoides. Chin Tradit Herb Drugs 2006; 37: $171-174$

[118] Fatima T, ljaz S, Crank G, Wasti S. Indole Alkaloids from Trachelospermum jasminoides. Planta Med 1987; 53: 57-59

[119] Li M. Research progress on pharmacological effects of Trachelospermum jasminoides. Technol Econ Guid 2017; (25): 152-153

[120] Li H, Zhu B, Xu Z. Research status of Caulis Trachelospermi. Cent South Pharm 2014; 12: 463-466

[121] Li J, Zhang Q, Zhang T. Research progress on Trachelospermum jasminoides. J Hebei Tradit Chin Med Pharmacol 2016; 31: 55-58

[122] Lai P, Fan C, Li A. The comparison of anti-inflammatory and analgesic effects of Trachelospermum jasminoides (Lindl.) Lem. and Ficus pumila L. Arch Tradit Chin Med 2003; 21: 154-155

[123] Zhao CC. Study on the extraction and purification technology of total flavonoids of Trachelospermum jasminoides and its anti-inflammatory and analgesic pharmacological effects [Dissertation]. LiaoNing: Liaoning medicine School; 2011

[124] Shi BB, Chen J, Bao MF, Zeng Y, Cai XH. Alkaloids isolated from Tabernaemontana bufalina display xanthine oxidase inhibitory activity. Phytochemistry 2019; 166: 112060

[125] Kim Y, Jung H], Kwon HJ. A natural small molecule voacangine inhibits angiogenesis both in vitro and in vivo. Biochem Biophys Res Commun 2012; 417: 330-334 